\title{
THE FIRST USE OF PURPOSE-BUILT ARTIFICIAL CHIMNEY SWIFT HABITAT IN MANITOBA
}

Nicole Firlotte

Manitoba Agriculture and Resource

Development

200 Saulteaux Crescent

Winnipeg, MB R3J 3W3

nicole.firlotte@gov.mb.ca

Timothy F. Poole

Manitoba Agriculture and Resource

Development

200 Saulteaux Crescent

Winnipeg, MB R3J 3W3

\section{Christian Artuso}

Environment and Climate Change

Canada

351 Boulevard Saint-Joseph

Gatineau, QC K1A OH3

C-Jae C. Breiter

Assiniboine Park Zoo

2595 Roblin Blvd

Winnipeg, MB R3R 2N7

Laura D. Burns

Assiniboine Park Zoo

2595 Roblin Blvd

Winnipeg, MB R3R 2N7

Stephen D. Petersen

Assiniboine Park Zoo

2595 Roblin Blvd

Winnipeg, MB R3R 2N7

\section{Barbara E. Stewart \\ Sila Consultants \\ 1218 Marchand Road \\ Howden, MB R5A $1 \mathrm{~J} 6$}

Robert E.A. Stewart

Sila Consultants

1218 Marchand Road

Howden, MB R5A 1 J6
The Chimney Swift (Chaetura pelagica) is a long-distant migratory bird that catches insects in flight. ${ }^{1}$ Chimney Swifts have adapted to urban environments by breeding in anthropogenic structures, primarily brick chimneys attached to buildings. ${ }^{1}$ Prior to the establishment of western settlements, Chimney Swifts nested in cavities in trees, switching to anthropogenic structures as a response to the clearing of riverine forests during urban expansion. ${ }^{1}$ A severe decline in the Canadian Chimney Swift population (estimated to be about 90 per cent from 1970-2017²) resulted in the species being listed as Threatened under both the federal Species At Risk Act ${ }^{3}$ and the Manitoba Endangered Species and Ecosystems Act ${ }^{3}$, and being listed globally as Vulnerable. ${ }^{4}$ The likely reasons for this decline include reduced availability of aerial insects ${ }^{3}$, demolishing, capping and lining of brick chimneys ${ }^{3}$, and reduced productivity due to severe weather events. ${ }^{3}$ To date, conservation action has been focused on the creation of new habitat by way of artificial chimneys in the form of free-standing towers ${ }^{5}$, retention and restoration of existing habitat, and public outreach. ${ }^{3}$

In Manitoba, the Chimney Swift nests in aspen parklands and along the southern boreal edge from Lac du Bonnet northwest to The Pas. ${ }^{6}$ The Manitoba Chimney Swift Initiative (MCSI), a partnership that includes representatives from Nature Manitoba, the Government of Manitoba, the Government of Canada, Birds Canada, and professional biologists, was established in 2007. Its aim was to reverse long-term population declines by replicating the Chimney Swift tower designs successfully deployed in multiple jurisdictions in the USA. 5,7 Recent data demonstrated a loss of habitable chimneys at a rate of 14.5 per cent over 10 years in southern Manitoba prompting the decision to explore habitat replacement as a reasonable mitigation measure. ${ }^{8}$ Seven 12-foot (3.66 m) free-standing chimneys following the design as described by Kyle and Kyle ${ }^{5}$ were constructed between 2008 and 2013 but to date there has been no evidence of Chimney Swifts using these structures. ${ }^{7}$

The failure of these towers to attract swifts and provide alternative breeding habitat has presented a challenge to conservationists, most notably in cases where the loss of known Chimney Swift habitat legally must be mitigated under the Manitoba Endangered Species and Ecosystems Act. MCSI believes that the primary reasons that the original towers failed to attract swifts was a lack of internal temperature stability (especially in May when the birds begin to select nesting habitat) and the short tower height. ${ }^{7}$ Jurisdictional by-laws in Winnipeg and surrounding towns prevented construction of free-standing structures taller than 12 feet $(3.66 \mathrm{~m})$. MCSI noted that rain water would wet the top of the internal wall up to $3 \mathrm{~m}$ of the $3.66 \mathrm{~m}$ towers, which could potentially threaten a nest constructed on the wall. ${ }^{7}$ Designing a tower that could provide temperature stability and be structurally sound at the maximum height became a priority for future mitigation.

An opportunity to construct a larger tower for Chimney Swifts was part of the re-development of a 
property in Winnipeg. In fall 2014, a large stack chimney attached to the Old Grace Hospital in the Wolseley neighbourhood which was used for multiple years by a nesting pair of Chimney Swifts, was removed due to structural degradation. A working group was established to design a 'made for Manitoba' Chimney Swift tower to replace the chimney.

The new artificial chimney was designed with a number of added elements lacking in the original plans. The replacement structure needed to be taller than $3.6 \mathrm{~m}$ and have added insulation, consequently requiring a variance from the City of Winnipeg and engineered drawings. The tower would also eventually need to be moved to a permanent location; hence, it was constructed in three modules each measuring $3.6 \mathrm{~m}$ high. Each module was connected on the outside by metal brackets, and a small internal lip was formed at the joint between sections. When constructed, the $10.8 \mathrm{~m}$ tower was set on a cement pad. Due to delays in construction, the tower was not erected until late July 2015, and Chimney Swifts were not observed using the tower ahead of fall migration. Subsequently, it was taken down and a new artificial chimney was incorporated into the new building.

Following the removal of the tower from the Old Grace Hospital site, the Province of Manitoba and MCSI developed a partnership with the Assiniboine Park Conservancy to provide a permanent home for the tower on Assiniboine Park Zoo grounds. The criteria for determining suitable location included proximity to trees as Chimney Swifts require twigs to build their nests ${ }^{1}$, access to foraging grounds around the Assiniboine River, proximity to other Chimney Swift nest and roost locations, and accessibility for volunteers to monitor the tower outside of zoo operating hours. Zoo staff were able to identify a site to meet the criteria within the grounds of the McFeetors Heavy Horse Centre and along the north perimeter of the zoo.

The tower was reconstructed in spring 2018 before the expected date when Chimney Swifts return to Manitoba (Figure 1). The tower was monitored from late May to mid-August by MCSI volunteers and Zoo staff. While no occupancy was detected in 2018, on 27 May 2018 a pair of Chimney Swifts were observed flying above the tower while 'V-ing' (T. Poole, unpublished data). ' $V$-ing' is thought to indicate pair bonding and involves the wings snapping upwards at an acute angle. ${ }^{1,9}$ Although no swifts were



FIGURE 1. The tower in its current location at Assiniboine Park Zoo. Note the three distinct sections, the supportive bracket around the base and the concrete pad. Photo credit: T. Poole. observed entering the tower in 2018 , the observed behaviour indicated interest but not selected it as a breeding site.

Monitoring restarted on 16 May 2019. On 7 June, Assiniboine Park Zoo staff observed two Chimney Swifts leaving the tower during the afternoon. This was the first confirmed use of a Chimney Swift tower in Manitoba. Throughout the summer, swifts were observed over, and entering the tower on a regular basis (Table 1, Figure 2). On 1 August, a single Chimney Swift made several failed attempts to enter the tower during daytime. Failed and clumsy attempts at entering a chimney are indicative of an inexperienced bird, associated with that a bonded pair may have shown 
TABLE 1. Summary of observations of the Chimney Swift Tower at Assiniboine Park Zoo during the 2019 monitoring season. Monitoring sessions were 60 to 90 minutes.

\begin{tabular}{|c|c|c|c|}
\hline DATE & TIME OF DAY & $\begin{array}{c}\text { NUMBER } \\
\text { RECORDED } \\
\text { INSIDE } \\
\text { TOWER }\end{array}$ & COMMENTS \\
\hline 16 May & Evening & 0 & Chimney Swifts in area but no entries \\
\hline 22 May & Evening & 0 & No Chimney Swifts observed \\
\hline 26 May & Evening & 0 & No Chimney Swifts observed \\
\hline 30 May & Evening & 0 & No Chimney Swifts observed \\
\hline 7 June & Morning & 2 & Exited the tower \\
\hline 8 June & Morning & 1 & $\begin{array}{l}\text { One Chimney Swift entry followed shortly by one } \\
\text { exit, indicative of possible nest building }\end{array}$ \\
\hline 9 June & Afternoon & 1 & Chimney Swift exited the tower \\
\hline 14 June & Morning & 0 & Chimney Swifts in area but no entries \\
\hline 14 June & Evening & 3 & $\begin{array}{l}\text { Nest building believed ongoing based on several } \\
\text { entries and exits before roosting }\end{array}$ \\
\hline 20 June & Morning & 3 & All entered tower \\
\hline 23 June & Evening & 3 & All entered tower \\
\hline 10 July & Evening & 2 & Entered tower \\
\hline 16 July & Evening & 1 & Chimney Swift entered tower \\
\hline 1 August & Morning & 1 & $\begin{array}{l}\text { Multiple failed attempts to enter tower, indicative } \\
\text { of a fledgling }\end{array}$ \\
\hline 8 August & Morning & 1 & Entered tower \\
\hline 22 August & Morning & 0 & No Chimney Swifts observed \\
\hline
\end{tabular}



FIGURE 2: Still image taken from a video of a Chimney Swift entering the tower. Photo credit: T. Poole. fledging. ${ }^{9}$ The observer also noted no obvious signs of molted feathers along the primary wing feathers, another indication that this was a fledged swift. ${ }^{9}$ This confirms that the Chimney Swifts using the tower successfully raised at least one chick to fledge. Monitoring continued until late August when no Chimney Swifts were observed and it was assumed that the birds had migrated (Table 1).

An inspection of the interior of the tower in September 2019 revealed that three, possibly four eggs hatched inside the tower. There was also a single unhatched egg and the carcass of a deceased adult bird. An inspection of the wall revealed that a nest had been constructed below the lip where the bottom section of the tower connects to the middle section, at a height of approximately $3.6 \mathrm{~m}$ from the base of the tower (Figure 3). Zoo staff retrieved the nest from the tower during the winter of 2020. The nest was empty, confirming that a minimum of three chicks fledged during the summer of 2019 .

\section{Discussion}

This is the first documented instance of Chimney Swifts using and attempting to breed in an artificial chimney in western Canada. ${ }^{*}$ The observed behaviour of one bird indicated that at least one chick fledged from the tower in early August. While it is possible that the fledgling observed came from a different nest site, as has been observed for sites within $100 \mathrm{~m}$ of each other in St. Adolphe (B. Stewart, per. comm 2019), the physical evidence indicates three to four Chimney Swifts were fledged from this artificial chimney.

The presence of a third Chimney Swift, and the regular observations of 
daytime use of the tower suggested that this breeding attempt was being supported by a helper, a nonbreeding swift believed to assist with incubation, brooding and feeding. ${ }^{1}$ The decomposing carcass of a dead swift in the tower may explain the disappearance of the third adult bird noted during observations. It is unclear as to how the bird died due to the state of decomposition.

\section{Conclusion}

The first example of a successful artificial chimney in Manitoba provides a blueprint for future habitat creation. This tower differed from previous, unsuccessful ones, in being significantly larger in both height and internal dimensions. The data have yet to be analysed but we also suspect the added insulation reduced internal temperature fluctuations. Regardless of which parameters made this tower successful, its success has significant conservation implications. It is possible to provide a suitable alternative breeding structure in Manitoba to mitigate for the loss of chimneys due to urban development,

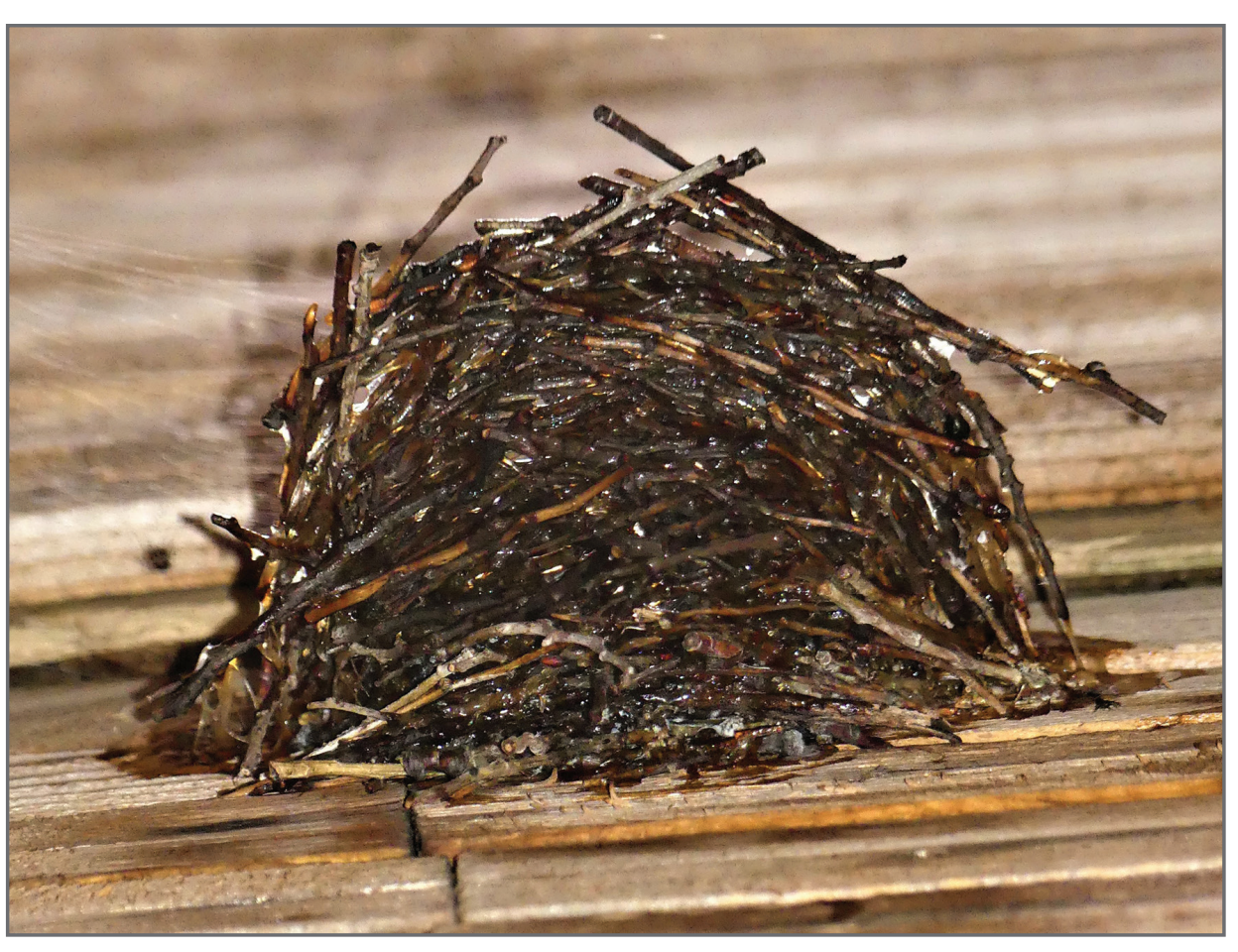

FIGURE 3. Nest on the wall of the tower, taken from underneath in September 2019. Photo credit: T. Poole.

heating system upgrades, and public safety. This is the second example of the Manitoba Endangered Species and Ecosystems Act being used to replace lost habitat. In the first instance, a chimney on an apartment in Winnipeg was unscreened following the lining of a second chimney on the same building. ${ }^{10}$ This project also demonstrates the value of partnerships across sectors for successful conservation. Developing such cross-sector partnerships will be key to conserving the Chimney Swift in Manitoba.

\section{Acknowledgements}

The Province of Manitoba funded the construction of the tower at the Old Grace Hospital site. Assiniboine Park Zoo and The Manitoba Bluebird Fund, a fund of Nature Manitoba, provided additional funding for moving and reconstructing the tower at the Assiniboine Park Zoo. Hannah Carey, Katrina Wilcox, Mitchell Green, Kirstyn Eckhardt, and Amber Papineau (Assiniboine Park Zoo), and Kelsey Bell, Frank Machovec and Jacquie Machovec (MCSI), provided additional monitoring data.
1. Steeves TK, Kearney-McGee SB, Rubega MA, Cink CL, Collins CT (2014) Chimney Swift (Chaetura pelagica). In The Birds of North America (P.G. Rodewald, editor). Retrieved from: http://bna.birds.cornell.edu/bna/ species/646 DOI: 10.2173/bna.646.

2. Smith AC, Hudson M-AR, Aponte V, Francis CM (2019) North American Breeding Bird Survey - Canadian Trends Website, Dataversion 2017. Environment and Climate Change Canada, Gatineau, Quebec, K1A OH3

3. COSEWIC (2018) COSEWIC assessment and status report on the Chimney Swift Chaetura pelagica in Canada. Committee on the Status of Endangered Wildlife in Canada. Ottawa. $x i i+63$ pp. (Species at Risk Public Registry).

4. BirdLife International (2019) Species factsheet: Chaetura pelagica. Downloaded from http://www.birdlife.org on 02/12/2019. Recommended citation for factsheets for more than one species: BirdLife International (2019) IUCN Red List for birds. Downloaded from http://www.birdlife.org on 02/12/2019.

5. Kyle PD, Kyle GZ (2005) Chimney Swift Towers. New habitat for America's mysterious birds. Texas A \& M University, College Station, TX.

6. Poole TF, Stewart BE, Stewart REA (2018) Chimney Swift In (C. Artuso, A.R. Couturier, K.D. De Smet, R.F. Koes, D. Lepage, J. McCracken, R.D. Mooi, and P. Taylor editors.). The Atlas of the Breeding Birds of Manitoba, 2010-2014. Bird Studies Canada. Winnipeg, Manitoba www.birdatlas.mb.ca/accounts/ speciesaccount.jsp?sp=CHSW\&lang=en [27 Dec 2019]

7. Manitoba Chimney Swift Initiative (2016). Guidelines for Creating Chimney Swift Nesting or Roosting Chimneys in Manitoba. www.mbchimneyswift.com/Documents/ artificialstructures2016.pdf [12 August 2019]

8. Stewart REA, Poole TF, Artuso C, Stewart BE (2017) Loss and Preservation of Chimney Swift habitat in Manitoba, 2007-2016. Blue Jay 75(2):11-15.

9. Stewart BE, Stewart REA (2011) Manitoba Chimney Swift Initiative guide for monitoring Chimney Swift nest sites: how to identify stages of nesting and determine breeding success. Report for the Manitoba Chimney Swift Initiative. Downloaded from www. mbchimneyswift.com/Documents/monitoring_ guide2011.pdf on December 202019.

10. Poole TF, Ogilvie, G (2020) Occupancy of unconventional nest and roost habitats by the Chimney Swift (Chaetura pelagica) in Manitoba. Blue Jay 78(1):10-15. 